\title{
Evaluation of cutaneous manifestations in patients under treatment with thyroid disease
}

\author{
Tedavi altındaki tiroid hastalarında deri bulgularının değerlendirilmesi
}

\section{Ersoy Acer, ๑ Esra Ağaoğlu, ๑ Göknur Yorulmaz*, ๑ Hilal Kaya Erdoğan, ๑ Elif Sevil Alagüney*, ๑ Zeynep Nurhan Saraçoğlu, ๑ Muzaffer Bilgin**}

Eskișehir Osmangazi University Faculty of Medicine, Department of Dermatology; *Department of Endocrinology and Metabolism;

**Department of Biostatistics, Eskișehir, Turkey

\begin{abstract}
Background and Design: Thyroid diseases often cause various findings in hair, skin and nails. Some of them may be regressed by the treatment of thyroid disease. We aimed to evaluate the cutaneous manifestations in patients with thyroid disease under treatment.

Materials and Methods: This cross-sectional study included 97 consecutive patients with thyroid disease under treatment and 50 healthy controls. Thyroid disease was classiffied as autoimmune and non-autoimmune. All skin findings and dermatological diseases were recorded. Results: Of the patient group, 56 (57.7\%) had autoimmune, 41 (43.3\%) had non-autoimmune thyroid disease. Eighty-four (86.4\%) patients were under thyroid hormone therapy and 13 (23.6\%) patients were under anti-thyroid therapy. $73.2 \%$ of the autoimmune group, $71.4 \%$ of non-autoimmune group and $52 \%$ of the control group had at least one cutaneous manifestation $(p=0.05)$. Xerosis ( $p=0.026)$, pruritus ( $p=0.00)$ facial erythema $(p=0.036)$, flushing $(p=0.004)$, dry hair $(p=0.008)$, brittle nails $(p=0.02)$, dry nails $(p=0.013)$ and longitudinal streaking on nails $(p=0.02)$ were more frequent in the autoimmune group than in the non-autoimmune and control group. Alopecia ( $p=0.00)$ was more frequent in the non-autoimmune group. Furthermore diffuse hyperhidrosis $(p=0.016)$, thinning of nails $(p=0.059)$ and rosacea disease $(p=0.03)$ were more common in the patient group than in the control group. At least one cutaneous manifestation, xerosis and various nail findings were more common in patients under thyroid hormone therapy than in patients under anti-thyroid therapy, but there was no statistically significant difference.

Conclusion: These findings have shown that various cutaneous manifestations can also be seen in patients with thyroid disease under treatment. We believe that further studies comparing thyroid patients who received and did not receive treatment are necessary to clarify the effect of thyroid disease treatment on cutaneous manifestations.
\end{abstract}

Keywords: Cutaneous manifestations, thyroid diseases, autoimmunity

\section{Öz}

Amaç: Tiroid hastalıkları sıkıkla saç, deri ve tırnaklarda çeşitli bulgulara neden olur. Bu bulguların bazıları tiroid hastalığının tedavisi ile gerileyebilir. Bu çalışmada tedavi altındaki tiroid hastalarında deri bulgularıı değerlendirmeyi amaçladık.

Gereç ve Yöntem: Bu kesitsel çalışmaya tedavi altındaki 97 tiroid hastası ve 50 sağlıklı kontrol dahil edildi. Tiroid hastalığı otoimmün ve nonotoimmün olarak sınıflandırıldı. Tüm deri bulguları ve dermatolojik hastalıklar kaydedildi.

Bulgular: Hasta grubunun 56'sında $(\% 57,7)$ otoimmün, 41'inde $(\% 43,3)$ non-otoimmün tiroid hastalığı mevcuttu. Seksen dört $(\% 86,4)$ hasta tiroid hormon tedavisi, $13(\% 23,6)$ hasta anti-tiroid tedavi alıyordu. Otoimmün grubun $\% 73,2$ 'sinde, non-otoimmün grubun $\% 71,4$ 'ünde ve kontrol grubunun $\% 52$ 'sinde en az bir deri bulgusu vardı $(p=0,05)$. Kseroz $(p=0,026)$, kaşıntı $(p=0,00)$, fasiyal eritem $(p=0,036)$, flushing $(p=0,004)$, kuru saç $(p=0,008)$, kırılgan tırnaklar $(p=0,02)$, kuru tırnaklar $(p=0,013)$ ve tırnaklarda uzunlamasına çizgiler $(p=0,02)$ otoimmün grupta non-otoimmün ve kontrol grubuna göre daha sıktı. Alopesi $(p=0,00)$ non-otoimmün grupta daha sıktı. Ayrıca, hasta grubunda diffüz hiperhidroz $(p=0,016)$, tırnaklarda incelme $(p=0,059)$ ve rozase hastalığı $(p=0,03)$ kontrol grubundan daha sıktı. Tiroid hormon tedavisi alanlarda, en az bir deri bulgusu, kserozis ve çeşitli tırnak bulguları anti-tiroid tedavi alanlara göre daha sıktı. Ancak istatistiksel olarak anlamlı bir fark yoktu.

Address for Correspondence/Yazışma Adresi: Ersoy Acer MD, Eskişehir Osmangazi University Faculty of Medicine, Department of Dermatology, Eskişehir, Turkey Phone: +90 5067147574 E-mail: ersoyacer@hotmail.com Received/Geliş Tarihi: 13.09.2019 Accepted/Kabul Tarihi: 21.02.2020 ORCID: orcid.org/0000-0002-6041-6636 
Sonuç: Bu bulgular, tedavi altındaki tiroid hastalarında da çeşitli deri bulgularının görülebileceğini göstermiştir. Tiroid hastalığı tedavisinin kütanöz bulgular üzerindeki etkisini netleştirmek için tedavi altında olan ve olmayan tiroid hastalarını karşılaştıran daha ileri çalışmaların gerekli olduğu düşünüyoruz.

Anahtar Kelimeler: Kütanöz bulgular, tiroid hastalıkları, otoimmünite

\section{Introduction}

Thyroid hormones (TH) play an important role in maintaining normal functions of the skin, so the first signs of TH imbalance are often seen in the skin. TH affects proteoglycan synthesis in the skin by stimulating fibroblasts. They also play a regulatory role in epidermal differentiation through their effects on keratinocytes. Furthermore, TH are very important in hair formation and sebum production ${ }^{1-3}$. Thyroid diseases often cause changes in hair, skin and nails. Therefore, dermatologists should be familiar with dermatological findings associated with thyroid diseases ${ }^{4}$. Some of these findings may regress with the treatment of thyroid disease; but some findings especially related with autoimmunity may not regress ${ }^{5}$.

To best of our knowledge, there is only one study evaluating cutaneous manifestations in patients with thyroid disease under treatment in the literature ${ }^{6}$. In this study, we aimed to evaluate the cutaneous manifestations in patients with thyroid disease under treatment.

\section{Materials and Methods}

Ninenty-seven consecutive patients with thyroid disease and 50 healthy controls aged over 18 years were included in this cross-sectional study. Patients were referred by endocrinology department of our hospital. Thyroid patients with untreated, under treatment for less than 1 year and newly diagnosed were excluded. Other exclusion criteria were pregnancy, lactation and having any other systemic diseases and medications. Ethical approval was received from the Eskişehir Osmangazi University, Non-interventional Clinical Research Ethics Committee (approval number: 43, date: 23.07.2019). Informed consent was obtained from all participants.

Graves' disease and Hashimoto's thyroiditis are autoimmune, whereas other diseases such as nodular and diffuse guatr are nonautoimmune thyroid diseases ${ }^{3}$. Patients with thyroid disease were classified as autoimmune and non-autoimmune by an endocrinologist. Dermatological examination of all patients and controls were performed by the same dermatologist. All cutaneous manifestations and dermatological diseases were recorded.

\section{Statistical Analysis}

IBM SPSS Statistics 21.0 (IBM Corp. Released 2012. IBM SPSS Statistics for Windows, Version 21.0. Armonk, NY: IBM Corp.) software was used for the data analyses. Continuous data was presented as mean \pm standard deviation and median. Categorical data was presented in percentage (\%). Pearson's chi-square and Pearson's exact chi-square was used to analyze the cross-tables. $\mathrm{P}<0.05$ value was accepted to be statistically significant.

\section{Results}

The study included 97 patients with thyroid disease [82 (84.5\%) female, $15(15.5 \%)$ male] and 50 healthy controls [38 (76.0\%) female,
$12(24.0 \%)$ male]. Mean age of patient group was $52.23 \pm 12.52$ years and mean age of control group was $54.40 \pm 14.83$ years. The groups were similar in terms of age and gender $(p>0.05)$. Mean disease duration was $7.84 \pm 2.14$ years in patient group. Of 97 patients with thyroid disease, 56 (57.7\%) were autoimmune, 41 (43.3\%) were nonautoimmune. Eighty-four (86.4\%) were on thyroid hormone therapy and $13(23.6 \%)$ were on anti-thyroid therapy. Mean treatment duration was $6.29 \pm 1.98$ years. At least one cutaneous manifestation was present in $73.2 \%$ of autoimmune group, $71.4 \%$ of non-autoimmune group and $52 \%$ of control group $(p=0.05)$. Xerosis $(p=0.026)$, pruritus $(p=0.00)$, facial erythema $(p=0.036)$, flushing $(p=0.004)$, dry hair $(p=0.008)$, brittle nails ( $p=0.02)$, dry nails ( $p=0.013)$, longitudinal streaking on nails $(p=0.02)$ were more frequent in the autoimmune group than the nonautoimmune and control groups. Alopecia $(p=0.00)$ was more frequent in non-autoimmune group (Table 1). In addition, in the patient group, diffuse hyperhidrosis $(p=0.016)$, nail thinning $(p=0.059)$ and rosacea $(p=0.03)$ were more frequent than the control group. When patient group were evaluated according to treatment; at least one cutaneous manifestation, xerosis, facial erythema and various nail findings were more common in thyroid hormone therapy group, whereas pruritus, diffuse hyperhidrosis and alopecia were more common in anti-thyroid therapy group but there was no statistically significant difference (Table 2).

\section{Discussion}

TH play important roles in maintaining normal skin functions. The effect of TH in cutaneous biology including epidermis, dermis and hair has been shown². Cutaneous manifestations usually occur after the development of thyroid disease; but they may be the first sign of thyroid disease. They can be divided into two main categories; 1 . Direct effect of TH on skin tissues 2. Skin diseases caused by autoimmune etiology $y^{2,7}$. Some of these findings may regress with the treatment of thyroid disease ${ }^{1,8}$. Previous studies have evaluated skin findings in thyroid patients before treatment. In these studies, at least one cutaneous manifestation was found in $81 \%$ and $56.8 \%$ of patients with thyroid disease ${ }^{5,8}$. In our study, skin findings before treatment were not evaluated and $72.1 \%$ of patients with thyroid disease on treatment had at least one cutaneous manifestation.

Thyroid diseases may cause various symptoms in hair, skin and nails 4 . Different cutaneous manifestations may be seen in hypothyroidism and hyperthyroidism ${ }^{1,4}$. In our study, there was no thyroid hormon levels of participants but they were categorized by thyroid hormone therapy and anti-thyroid therapy groups. At least one cutaneous manifestation, xerosis, facial erythema and various nail findings were more common in thyroid hormone therapy group, whereas pruritus, diffuse hyperhidrosis and alopecia was more common in anti-thyroid therapy group but there was no statistically significant difference. This results may be related to the fact that the number of participants in the groups were not similar. The skin is characteristically cold, xerotic and pale in hypothyroidism ${ }^{1,49,10}$. The cause of cold skin is peripheral vasoconstriction. Xerosis is 


\section{Table 1. Cutaneous manifestations in autoimmune, non-autoimmune and control groups}

\begin{tabular}{|c|c|c|c|c|}
\hline & $\begin{array}{l}\text { Autoimmune group } \\
(n=41), n(\%)\end{array}$ & $\begin{array}{l}\text { Non-autoimmune group } \\
(n=56), n(\%)\end{array}$ & $\begin{array}{l}\text { Control group } \\
(n=50), n(\%)\end{array}$ & $\mathbf{p}^{*}$ \\
\hline At least one cutaneous manifestation & $30(73.2)$ & $40(71.4)$ & $26(52.0)$ & 0.05 \\
\hline Xerosis & $18(43.9)$ & $23(41.1)$ & $10(20.0)$ & 0.026 \\
\hline Pruritus & $17(41.5)$ & $18(32.1)$ & $2(4.0)$ & 0.00 \\
\hline Moist skin & 0 & 0 & 0 & - \\
\hline Yellow skin & 0 & 0 & 0 & - \\
\hline Diffuse hyperhidrosis & $4(9.8)$ & $6(10.7)$ & $0(0)$ & 0.062 \\
\hline Palmoplantar hyperhidrosis & $1(2.4)$ & $1(1.8)$ & $0(0)$ & 0.747 \\
\hline Palmoplantar hyperkeratosis & 0 & 0 & 0 & - \\
\hline Facial erythema & $9(22.0)$ & $9(16.1)$ & $2(4.0)$ & 0.036 \\
\hline Flushing & $7(17.1)$ & $3(5.4)$ & $0(0)$ & 0.004 \\
\hline Periorbital edema & $2(4.9)$ & $2(3.6)$ & $0(0)$ & 0.458 \\
\hline Pretibial myxedema & 0 & 0 & 0 & - \\
\hline Diffuse edema & $1(2.4)$ & $0(0)$ & $0(0)$ & 0.282 \\
\hline Xanthelasma & $0(0)$ & $1(1.8)$ & $0(0)$ & 1.00 \\
\hline Local hyperpigmentation & $1(2.4)$ & $0(0)$ & $1(2.0)$ & 0.53 \\
\hline Diffuse hyperpigmentation & 0 & 0 & 0 & - \\
\hline Melasma & $2(4.9)$ & $7(12.5)$ & $2(4.0)$ & 0.21 \\
\hline Acanthosis nigricans & 0 & 0 & 0 & - \\
\hline Keratosis pilaris & $2(4.9)$ & $1(1.8)$ & $0(0)$ & 0.27 \\
\hline Eyebrow loss & $2(4.9)$ & $4(7.1)$ & $0(0)$ & 0.17 \\
\hline Alopecia & $29(70.7)$ & $40(71.4)$ & $18(36.0)$ & 0.00 \\
\hline Dandruff & $7(17.1)$ & $8(14.3)$ & $7(14.0)$ & 0.90 \\
\hline Hair graying & $38(92.7)$ & $51(91.1)$ & $48(96.0)$ & 0.652 \\
\hline Hair dryness & $6(14.6)$ & $9(16.1)$ & $0(0)$ & 0.013 \\
\hline Alopecia areata & $0(0)$ & $1(1.8)$ & $0(0)$ & 1.00 \\
\hline Seborrheic dermatitis & $2(4.9)$ & $3(5.4)$ & $0(0)$ & 0.26 \\
\hline Shiny nails & $0(0)$ & $1(1.8)$ & $0(0)$ & 1.00 \\
\hline Soft nails & $3(7.3)$ & $2(3.6)$ & $0(0)$ & 0.15 \\
\hline Fine nails & $5(12.2)$ & $6(10.7)$ & $1(2.0)$ & 0.13 \\
\hline Brittle nails & $9(22.0)$ & $11(19.6)$ & $2(4.0)$ & 0.02 \\
\hline Dry nails & $3(7.3)$ & $6(10.7)$ & $0(0)$ & 0.63 \\
\hline Rough nails & $0(0)$ & $1(1.8)$ & $0(0)$ & 1.00 \\
\hline Onycholysis & $0(0)$ & $2(3.6)$ & $0(0)$ & 0.33 \\
\hline Distal separation & $0(0)$ & $2(3.6)$ & $0(0)$ & 0.33 \\
\hline Hyperkeratotic nails & $1(2.4)$ & $1(1.8)$ & $0(0)$ & 0.74 \\
\hline Transverse streaking on nails & $1(2.4)$ & $0(0)$ & $0(0)$ & 0.28 \\
\hline Longitudinal streaking on nails & $6(14.6)$ & $5(8.9)$ & $0(0)$ & 0.02 \\
\hline Clubbing & 0 & 0 & 0 & - \\
\hline Vitiligo & $0(0)$ & $0(0)$ & $1(2.0)$ & 0.624 \\
\hline Psoriasis & $1(2.4)$ & $4(7.1)$ & $0(0)$ & 0.10 \\
\hline Urticaria & $1(2.4)$ & $2(3.6)$ & $0(0)$ & 0.63 \\
\hline Rosacea & $7(17.1)$ & $12(21.4)$ & $3(6.0)$ & 0.077 \\
\hline Acne & $2(4.9)$ & $1(1.8)$ & $1(2.0)$ & 0.67 \\
\hline Contact dermatitis & $4(9.8)$ & $2(3.6)$ & $2(4.0)$ & 0.43 \\
\hline \multicolumn{5}{|l|}{ *Pearson's chi-square } \\
\hline
\end{tabular}


caused by peripheral vasoconstriction, reduction in epidermal sterol biosynthesis and sebaceous gland secretion and hypohidrosis $1,2,10$. In previous studies, xerosis was observed in $37-45 \%$ of patients with

Table 2. Cutaneous manifestations in anti-thyroid and thyroid hormone groups

\begin{tabular}{|c|c|c|c|}
\hline & $\begin{array}{l}\text { Anti-thyroid } \\
\text { group } \\
(n=13), n(\%)\end{array}$ & $\begin{array}{l}\text { Thyroid } \\
\text { hormone } \\
\text { group }(n=84) \text {, } \\
n(\%)\end{array}$ & $\mathbf{p}^{*}$ \\
\hline $\begin{array}{l}\text { At least one cutaneous } \\
\text { manifestation }\end{array}$ & $8(61.5)$ & $62(73.8)$ & 0.50 \\
\hline Xerosis & $2(15.4)$ & $39(46.4)$ & 0.06 \\
\hline Pruritus & $7(53.8)$ & $28(33.3)$ & 0.21 \\
\hline Diffuse hyperhidrosis & $2(15.4)$ & $8(9.5)$ & 0.61 \\
\hline Palmoplantar hyperhidrosis & 0 & $2(2.4)$ & 1.00 \\
\hline Facial erythema & $1(7.7)$ & $17(20.2)$ & 0.45 \\
\hline Flushing & $1(7.7)$ & $9(10.7)$ & 1.00 \\
\hline Periorbital edema & 0 & $4(4.8)$ & 0.64 \\
\hline Diffuse edema & 0 & $1(1.2)$ & 1.00 \\
\hline Xanthelasma & $0(0)$ & $1(1.2)$ & 1.00 \\
\hline Local hyperpigmentation & $0(0)$ & $1(1.2)$ & 1.00 \\
\hline Melasma & $2(15.4)$ & $7(8.3)$ & 0.60 \\
\hline Keratosis pilaris & $1(7.7)$ & $2(2.4)$ & 0.35 \\
\hline Eyebrow loss & $0(0)$ & $6(7.1)$ & 0.59 \\
\hline Alopecia & $9(69.2)$ & $4(30.8)$ & 1.00 \\
\hline Dandruff & $1(7.7)$ & $14(16.7)$ & 0.47 \\
\hline Hair graying & $10(76.9)$ & $79(94.0)$ & 0.07 \\
\hline Hair dryness & $1(7.7)$ & $14(16.7)$ & 0.47 \\
\hline Alopecia areata & $0(0)$ & $1(1.2)$ & 1.00 \\
\hline Seborrheic dermatitis & $0(0)$ & $5(6.0)$ & 0.61 \\
\hline Shiny nails & $0(0)$ & $1(1.2)$ & 1.00 \\
\hline Soft nails & $1(7.7)$ & $4(4.8)$ & 0.65 \\
\hline Fine nails & $0(0)$ & $11(13.1)$ & 0.35 \\
\hline Brittle nails & $2(15.4)$ & $18(21.4)$ & 0.73 \\
\hline Dry nails & $1(7.7)$ & $8(9.5)$ & 1.00 \\
\hline Rough nails & $0(0)$ & $1(1.2)$ & 1.00 \\
\hline Onycholysis & $0(0)$ & $2(2.4)$ & 1.00 \\
\hline Distal separation & $0(0)$ & $2(2.4)$ & 1.00 \\
\hline Hyperkeratotic nails & $1(7.7)$ & $1(1.2)$ & 0.25 \\
\hline $\begin{array}{l}\text { Transverse streaking on } \\
\text { nails }\end{array}$ & $0(0)$ & $1(1.2)$ & 1.00 \\
\hline $\begin{array}{l}\text { Longitudinal streaking on } \\
\text { nails }\end{array}$ & $1(7.7)$ & $10(11.9)$ & 1.00 \\
\hline Psoriasis & $1(7.7)$ & $4(4.8)$ & 0.65 \\
\hline Urticaria & $0(0)$ & $3(3.6)$ & 1.00 \\
\hline Rosacea & $1(7.7)$ & $18(21.4)$ & 0.30 \\
\hline Acne & $0(0)$ & $3(3.6)$ & 1.00 \\
\hline Contact dermatitis & $2(15.4)$ & $4(4.8)$ & 0.18 \\
\hline
\end{tabular}

thyroid disease, respectively ${ }^{6,8}$. In our study, $42.2 \%$ of patients with thyroid disease had xerosis and it was the most common cutaneous manifestation. Pruritus (36.1\%) was one of the most common cutaneous manifestation in our study similar to literature ${ }^{8}$. Xerosis is the most common skin finding in hypothyroidism². In our study, xerosis was more common in thyroid hormone therapy group but there was no statistically significant difference in our study.

Skin is warm, soft, moist, smooth and also itchy in patients with hyperthyroidism ${ }^{2,4,9,10}$. Warmth is caused by increased cutaneous blood flow. The moisture is a reflection of the underlying metabolic situation. In addition, facial erythema, flushing, palmar erythema, palmoplantar and diffuse hyperhidrosis may be seen ${ }^{2,9,10}$. In our study, facial erythema, flushing and diffuse hyperhidrosis were the common cutaneous manifestations similar to literature ${ }^{8}$.

The hairs of scalp and body are usually dry, rough and brittle in hypothyroidism ${ }^{1,2,10}$. Dry hair is one of the most common cutaneous findings in patients with thyroid disease $e^{6,8}$. In our study, it was also one of the most common cutaneous manifestation. Patients with thyroid disease often have diffuse or partial alopecia ${ }^{1,2,4,10}$. In previous studies, alopecia was observed in $32.3 \%-45 \%$ of patients with thyroid disease $e^{6,8}$. In our study, $72.1 \%$ of patients had alopecia. The high rate may be related with higher mean age of our patient group. The loss of the lateral third of the eyebrows is one of the common cutaneous manifestations in patients with both hyperthyroidism and hypothyroidism ${ }^{1,2,9,10}$. Six patients $(6.2 \%)$ had this finding in our study. Localized and generalized hyperpigmentation may be seen in patients with hyperthyroidism ${ }^{2,10}$. It is thought to be caused by increased pituitary adrenocorticotropic hormone ${ }^{2}$. In addition, it has been reported that there is a relationship between melasma and thyroid autoimmunity ${ }^{11,12}$ In a previous study, Dogra et al. ${ }^{13}$ reported that $18.7 \%$ of patients with hypothyroid had melasma and $6.2 \%$ had periocular pigmentation. Melasma was more common in patients with thyroid disease $(9.3 \%)$ in our study; but there was not statistically significant difference.

Patients with thyroid disease may have various nail findings. Dry, brittle, dull nails and longitudinal and transverse streakings on nails may be seen in hypothyroidism patients; whereas shiny, soft, friable nails and Plummer's nails (distal onycolysis) in hyperthyroidism patients 1,2,4,9,10. In a previous study it was reported that $64 \%$ of thyroid disease patients had nail findings and the most common nail findings were longitudinal streaking on nails and distal onycholysis 6 . Takir et al. ${ }^{8}$ reported that the most common nail findings were brittle nail (22.0\%) and nail thinning $(13.0 \%)$ in patients with thyroid disease. In our study, brittle nail (20.6\%) and longitudinal streaking on nail (11.3\%) were more common in thyroid patients. In addition nail findings were more common in thyroid hormone therapy group than anti-thyroid therapy group but the difference was not significant.

There may be a relationship between thyroid diseases and inflammatory skin diseases. It was reported that psoriasis and rosacea were associated with thyroid diseases in recent studies ${ }^{5,14,15}$. In our study, rosacea (19.6\%) was more frequent in patients with thyroid disease than healthy controls. Five (5.2\%) patients had psoriasis; but there was no statistically significant difference.

Thyroid autoimmunity is often associated with various skin diseases such as vitiligo, pemphigus, chronic urticaria, dermatitis herpetiformis, connective tissue diseases and alopecia areata ${ }^{2-4,7,10}$. These skin findings may be related to thyroid hormone levels or T and/or B-cell 
abnormalities $^{2}$. Cutaneous manifestations are more common in autoimmune thyroid diseases ${ }^{8}$. In our study, skin findings were also more common in patients with autoimmune thyroid disease. Previous studies have shown a relationship between chronic urticaria, vitiligo, alopecia areata and rosacea and thyroid autoimmunity,8,15-19. In our study, chronic urticaria was more common in patients with thyroid disease; but there was no statistically significant difference. There was no another autoimmune skin disease in patients with thyroid disease in our study. Vitiligo and alopecia areata usually occur many years before thyroid dysfunction. Therefore, the presence of high thyroid autoantibodies in these patients may serve as a useful clinical tool to identify patients at risk for thyroid diseases ${ }^{2,18,19}$.

In summary, alopecia, xerosis, pruritus, diffuse hyperhidrosis, various nail findings and rosacea were more common in patients with thyroid disease in our study. Furthermore, in this study the most common cutaneous manifestations were generally similar to the other studies in not receiving treatment patients with thyroid disease $e^{5,8}$. These results suggested that some cutaneous manifestations may be seen in thyroid disease patients on treatment too.

\section{Study Limitation}

Limitations of this study were relatively small sample size, absence of thyroid hormone levels in participants and absence of untreated group.

\section{Conclusion}

Various cutaneous manifestations may be seen in patients with thyroid disease on treatment too. We conclude that further studies which comparing thyroid patients on treatment and non-treatment are needed in order to clarify the effect of treatment of thyroid disease on cutaneous manifestations.

\section{Ethics}

Ethics Committee Approval: Ethical approval was received from the Eskişehir Osmangazi University, Non-interventional Clinical Research Ethics Committee (approval number: 43, date: 23.07.2019).

Informed Consent: Informed consent was obtained from all participants.

Peer-review: Externally peer-reviewed.

\section{Authorship Contributions}

Concept: E.A., E.Ağ., G.Y. Design: E.A., E.Ağ., G.Y., H.K.E., E.S.A., Z.N.S., M.B., Data Collection or Processing: E.A., E.Ağ., G.Y., H.K.E., E.S.A. Analysis or Interpretation: E.A., E.Ağ., G.Y., H.K.E., M.B., Literature Search: E.A., E.Ağ., G.Y., H.K.E., E.S.A., Writing: E.A., E.Ağ., G.Y., H.K.E., E.S.A., Z.N.S., M.B.
Conflict of Interest: No conflict of interest was declared by the authors.

Financial Disclosure: The authors declared that this study received no financial support.

\section{Referencess}

1. Doshi DN, Blyumin ML, Kimball AB: Cutaneous manifestations of thyroid disease. Clin Dematol 2008;26:283-7.

2. Kasumagic- Halilovic E: Thyroid disease and the skin. Annals Thyroid Res 2014;1:27-31.

3. Ai J, Leonhardt JM, Heymann WR. Autoimmune thyroid diseases: etiology, pathogenesis, and dermatologic manifestations. I Am Acad Dermatol 2003;48:641-62.

4. Burman KD, McKinley-Grant L: Dermatologic aspects of thyroid disease. Clin Dermatol 2006;4:247-55.

5. Artantaş S, Gül U, Kiliç A, Güler S: Skin findings in thyroid diseases. Eur J Intern Med 2009;20:158-61.

6. Özbağçıan Ö, Akarsu S, Fetil E: Tip II diabetes mellitus ve tiroid hastalarında gözlenen deri bulguları ve karşılaştııılması. DEÜ Tıp Fakültesi Dergisi 2014;28:7-14.

7. Safer JD: Thyroid hormone action on skin. Dermatoendocrinol 2011;3:211 5.

8. Takir $M$, Özlü $E$, Köstek $O$, et al: Skin findings in autoimmune and nonautoimmune thyroid disease with respect to thyroid functional status and healthy controls. Turk J Med Sci 2017:47:767-70.

9. Puri N: A study on cutaneous manifestations of thyroid disease. Indian J Dermatol 2012;57:247-8.

10. Jabbour SA: Cutaneous manifestations of endocrine disorders: a guide for dermatologists. Am J Clin Dermatol 2003;4:315-31.

11. Rostami Mogaddam M, Iranparvar Alamdari M, Maleki N, Safavi Ardabili $\mathrm{N}$, Abedkouhi S: Evaluation of autoimmune thyroid disease in melasma. $J$ Cosmet Dermatol 2015;14:167-71.

12. Kheradmand M, Afshari M, Damiani G, Abediankenari S, Moosazadeh $M$ : Melasma and thyroid disorders: a systematic review and meta-analysis. Int J Dermatol 2019;58:1231-8.

13. Dogra A, Dua A, Singh P: Thyroid and skin. Indian J Dermatol 2006;51:96-9

14. Wang SH, Wang J, Lin YS, Tung TH, Chi CC: Increased risk for incident thyroid diseases in people with psoriatic disease: a cohort study. J Am Acad Dermatol 2019;80:1006-12.

15. Berksoy Hayta S, Guner R, Cam S, Akyol M: Rosacea is associated with thyroid autoimmunity: a case control study. Acta Endocrinol (Buchar) 2018;14:248-51.

16. Kasumagic-Halilovic E, Beslic N, Ovcina-Kurtovic N: Thyroid autoimmunity in patients with chronic urticaria. Med Arch 2017;71:29-31.

17. Kim YS, Han K, Lee JH, et al: Increased risk of chronic spontaneous urticaria in patients with autoimmune thyroid diseases: a nationwide, populationbased study. Allergy Asthma Immunol Res 2017;9:373-7.

18. Fan KC, Yang TH, Huang YC: Vitiligo and thyroid disease: a systemic review and meta-analysis. Eur J Dermatol 2018;28:750-63.

19. Lee $S$, Lee $Y B$, Kim BJ, Lee WS: Screening of thyroid function and autoantibodies in patients with alopecia areata: a systemic review and metaanalysis. J Am Acad Dermatol 2019;80:1410-3.e4. 